Tropical Journal of Pharmaceutical Research June 2017; 16 (6): 1245-1251

ISSN: $1596-5996$ (print); 1596-9827 (electronic)

(C) Pharmacotherapy Group, Faculty of Pharmacy, University of Benin, Benin City, 300001 Nigeria.

All rights reserved.

Available online at http://www.tjpr.org

Original Research Article

http://dx.doi.org/10.4314/tjpr.v16i6.6

\title{
Relationship between four tumor-associated bio-markers and prognosis of gastric cancer
}

\author{
Xuyang Wen ${ }^{1,2}$, Qianwen $\mathrm{Li}^{3}$, Yunxiang $\mathrm{Du}^{3}$, Yan Shi ${ }^{4}$, Jing Yuan ${ }^{5}$, Li Chen ${ }^{2}$, \\ Qiong Sun ${ }^{2}$ and Guanghai Dai ${ }^{2 *}$ \\ 'Medical Oncology Department, People's Liberation Army 82nd Hospital, Huai'an 223001. Jiangsu Province, PR China, \\ ${ }^{2}$ Medical Oncology Department, People's Liberation Army General Hospital, Beijing 100853, PR China, ${ }^{3}$ Rediotherapy \\ Department, People's Liberation Army 82nd Hospital, Huai'an 223001, Jiangsu Province, PR China, ${ }^{4}$ Department of Oncology \\ Multimodality Therapy, ${ }^{5}$ Department of Pathology, People's Liberation Army General Hospital, Beijing 100853, PR China \\ *For correspondence: Email: guanghaidai82@163.com; Tel: +86-010-66887329
}

Sent for review: 18 January 2017

Revised accepted: 11 May 2017

\begin{abstract}
Purpose: To investigate the relationship between prognosis of gastric cancer (GC) and the expression of P53, Epidermal growth factor receptor (EGFR), Human epidermal growth factor receptor-2 (HER-2), and Vascular endothelial growth factor (VEGF).

Methods: One hundred and forty-seven patients admitted to People's Liberation Army General Hospital (Beijing, China) with diagnosis of locally advanced GC were enrolled in the study. Follow-up data were obtained by outpatient review or telephone follow-up. Expressions of P53, EGFR, HER-2 and VEGF were determined by immunohistochemical staining. The relationship between protein expression, clinico-pathological factors, disease-free survival time (DFS) and overall survival (OS) were analyzed.

Results: The expressions of EGER, HER-2, P53 and VEGF in GC were 17.7, 17.0, 41.0 and 55.9\%, respectively. The expressions of EGFR and P53 were positively correlated $(r=0.306, p<0.05)$, while the expressions of VEGF and HER-2 were negatively correlated $(r=-0.2, p<0.05)$. The expressions of EGFR, HER-2 and VEGF were not related to the clinico-pathological factors $(p>0.05)$ while expression of P53 was related only to histological grade $(p<0.05)$. Univariate analysis showed that OS and DFS were longer $(p<0.05)$ when P53 was lowly expressed. Multiple-factor analysis revealed that histological grade, infiltration depth and P53 expression were independent factors that influenced DFS.

Conclusion: These results indicate that the expression of P53, EGFR, HER2 and VEGF can be used to predict prognosis of GC and screening of patients' benefits from adjuvant chemotherapy.
\end{abstract}

Keywords: Gastric cancer, Prognosis, Biomarkers, Adjuvant chemotherapy

Tropical Journal of Pharmaceutical Research is indexed by Science Citation Index (SciSearch), Scopus, International Pharmaceutical Abstract, Chemical Abstracts, Embase, Index Copernicus, EBSCO, African Index Medicus, JournalSeek, Journal Citation Reports/Science Edition, Directory of Open Access Journals (DOAJ), African Journal Online, Bioline International, Open-J-Gate and Pharmacy Abstracts

\section{INTRODUCTION}

Gastric cancer (GC) is the fifth most common malignant disease and is the third leading cause of cancer deaths in both sexes worldwide [1]. In China, GC is currently the second most common cancer and second leading cause of cancer death [2]. Although the incidence of $\mathrm{GC}$ has declined recently, a 2016 study showed that the 5-year survival was less than $30 \%$ [3].
However, recent progress in research on recombinant humanized anti-HER2 antibody (Herceptin) in the treatment of HER2-positive expression GC has aroused considerable interest in prognosis-related biomarkers and GC sensitivity to chemotherapy [4]. Indicators of P53, EGFR, HER2, and VEGF. in GC have been extensively investigated [5]. However, not much is known about the predictive roles of these 
indicators in adjuvant chemotherapy after GC surgery. In addition, Meta-analysis has proved that adjuvant treatment with 5-fluorouracil (5-FU) after radical surgery in GC was beneficial to patients' survival [6].

The present study was designed to evaluate the expression of P53, EGFR, HER2 and VEGF in GC patients who received adjuvant treatment of 5-FU after radical surgery. The relationship of these biomarkers and clinico-pathologic characteristics, treatment and survival were also investigated.

\section{METHODS}

\section{Study population}

One hundred and forty seven patients admitted to Chinese People's Liberation Army General Hospital (Beijing, China) with a diagnosis of locally advanced GC (I -IV stage), were studied. All the patients accepted D2 radical operation and adjuvant chemotherapy with 5-FU for 4 cycles after surgery. Histological examination showed that the patients did not receive any neoadjuvant chemotherapy prior to surgery. Followup was from the day of surgery to March 11, 2010 (about 3 to 5 years), and the data were obtained by outpatient review or telephone follow-up. The present study was approved by the Ethical Committee of Chinese People's Liberation Army General Hospital (approval no. 0718-1[H]) and was carried out in accordance with the Declaration of Helsinki [7]. All patients gave their consent to participate in the study.

\section{Definitions}

Disease-free survival time (DFS) was defined as the period from surgery to the start of tumor progression or the end of follow-up. Overall survival (OS) was defined as the time between surgery and death or the end of follow-up of patient. The patients were divided into 11 cases of stage I, 44 cases of stage II, 61 cases of stage IIIA, 25 cases of stage IIIB and 6 cases of stage IV according to the TNM staging criteria for gastric cancer Union for International Cancer Control (UICC) [8]. There were 124 male patients and 23 female patients, with age range of 31-78 years (median 54.57 years). Histopathological examination showed 89 cases of adenocarcinoma, 26 cases of signet ring cell carcinoma, and 32 cases of mixed type. In addition, there were 36 cases of gastric fundus and cardia, 54 cases of gastric body, and 57 cases of gastric antrum. Adjuvant chemotherapy was divided into 3 categories:
Treatment prescription I (DCF, 25 cases): taxotere (TXT, $60 \mathrm{mg} / \mathrm{m}^{2}, 1^{\text {st }}$ day); cisDichlorodiamine platinum (DDP, $30 \mathrm{mg} / \mathrm{m}^{2}, 1^{\text {st }}$ day to $3^{\text {rd }}$ day); $5-\mathrm{FU}\left[400 \mathrm{mg} / \mathrm{m}^{2}\right.$, intravenous injection (i.v.), $1^{\text {st }}$ day]; calcium folinate (CF, 200 $\mathrm{mg} / \mathrm{m}^{2}, 1^{\text {st }}$ day) and 5 -FU $\left[2.4 \mathrm{~g} / \mathrm{m}^{2}\right.$, continuous intravenous injection (CIV) for $48 \mathrm{~h}$ ].

Treatment prescription I/ (FOLFOX-4, 90 cases): oxaliplatin (LOHP, $130 \mathrm{mg} / \mathrm{m}^{2}, 1^{\text {st }}$ day); 5-FU [400 mg/m $\mathrm{m}^{2}$ (i.v.), $1^{\text {st }}$ day]; CF, $\left(200 \mathrm{mg} / \mathrm{m}^{2}, 1^{\text {st }}\right.$ day); and $5-\mathrm{FU}\left(2.4 \mathrm{~g} / \mathrm{m}^{2}\right.$, CIV for $\left.48 \mathrm{~h}\right)$.

Treatment prescription III (DOF, 10 cases): TXT $\left(60 \mathrm{mg} / \mathrm{m}^{2}, 1^{\text {st }}\right.$ day); LOHP $\left(130 \mathrm{mg} / \mathrm{m}^{2}, 1^{\text {st }}\right.$ day); 5 -FU (400 mg/m $\mathrm{m}^{2}$, i.v., 1st day); CF $\left(200 \mathrm{mg} / \mathrm{m}^{2}\right.$, 1 st day) and $5-\mathrm{FU}\left(2.4 \mathrm{~g} / \mathrm{m}^{2}\right.$, CIV for $\left.48 \mathrm{~h}\right)$.

\section{Immunohistochemistry}

Samples were collected from patients who underwent GC surgery from January 2004 to December 2007 at Chinese People's Liberation Army General Hospital (Beijing, China). Samples were formaldehyde-fixed and paraffin-embedded, and cut at a thickness of $4 \mu \mathrm{m}$ for immunohistochemical staining. The following antibodies were used for immune-stainings: EGER (Leica, dilution 1:100), P53 (DAKO, dilution 1:100), HER-2 (DAKO, dilution 1:100), VEGF (ZSGB-BIO, dilution 1:200). Immunohistochemical staining was performed on an Envision biotin-free detection system (DAKO).

\section{Data evaluation}

EGER and HER-2 proteins were stained brown and located in the cell membrane: If the cell membrane was not stained or if the number of positive cells was $<10 \%$, the samples was rated $(-)$; if the number of positive cells was $\geq 10 \%$ and cell membrane was incomplete, the sample was rated $(+)$; if the number of positive cells was $\geq 10$ $\%$ and the cell membrane was complete and lightly or moderately-stained, the sample was grouped as $(++)$; when the number of positive cells was $\geq 10 \%$, and the cell membrane was complete and severely stained, the sample was rated (+++). P53 and VEGF proteins were stained brown and located in cell nucleus. The staining was divided into 4 levels on the basis of average percentage of positive cells in 100 cells under 10 high-power microscope fields. The mean values were designated as follows: $0=(-)$, $\leq 25 \%=(+),>25 \%$ but $\leq 50 \%=(++),>50 \%$ but $\leq 75 \%=(+++)$ and $>75 \%=(++++)$. All average values designated as $(-)$ and $(+)$ were taken as negative, while average values designated $(++),(+++),(++++)$ were regarded as positive. 


\section{Statistical analysis}

Statistical analysis was performed using PASW Statistics 18.0 software (SPSS, Inc., Chicago, $\mathrm{IL})$. Comparison of ratings were analyzed using $\mathrm{X}^{2}$ test, correlation analyses were carried out using Spearman's test, while survival rate was calculated by Meier-Kaplan single factor analysis using log - rank test. Multiple factor-survival analysis was performed by COX regression. $p<$ 0.05 was considered statistically significant.

\section{RESULTS}

\section{Immunohistochemistry}

EGER and HER-2 proteins were located in the cell membrane and cytoplasm, while P53 and VEGF proteins were located in cell nucleus (Figure 1). The expressions of EGER, HER-2, P53 and VEGF in GC were 17.7, 17.0, 41.0 and $55.9 \%$, respectively.

\section{Correlation analysis}

The expressions of EGFR and P53 were positively correlated $(r=0.306, p<0.05)$, while
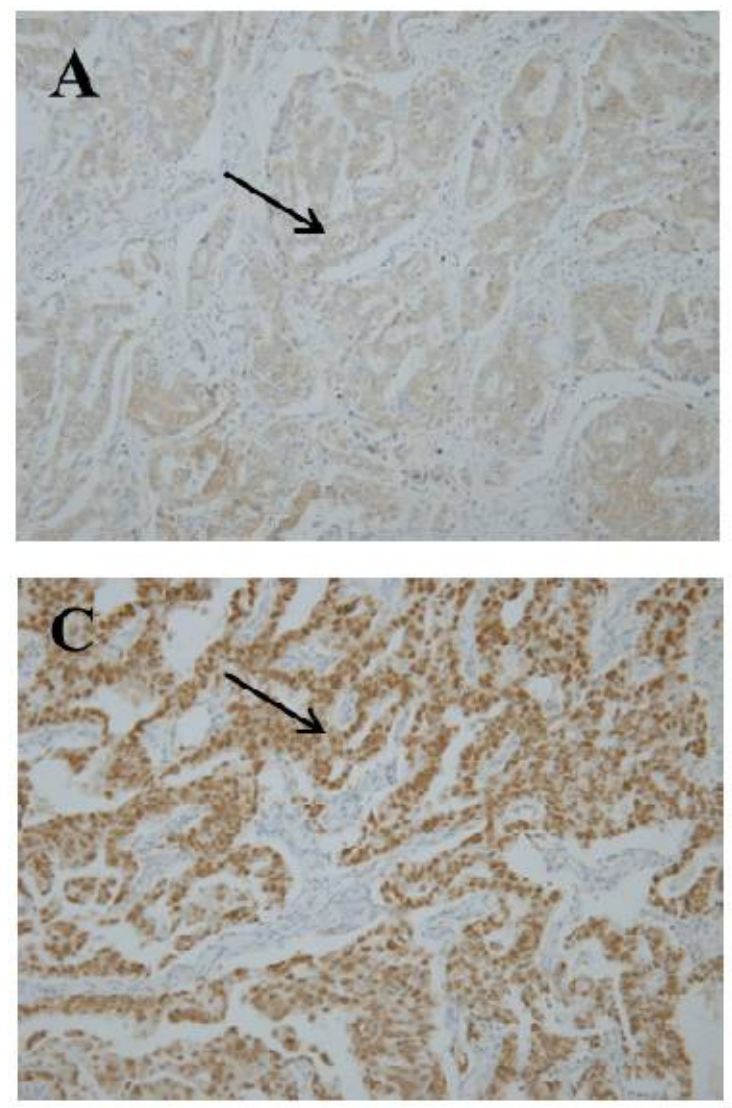

Figure 1: Positive expressions of HER-2 (A), EGFR envision methods) the expressions of VEGF and HER-2 were negatively correlated $(r=-0.2, p<0.05)$.

\section{Relationship between protein expression and clinico-pathological factors}

Results on Table 1 showed that the expressions of EGFR, HER-2, VEGF were not linked to sex, age, pathology, histological grade, stage of GC, presence of tumor thrombus, tumor size, location and other clinico-pathological factors $(p>0.05)$. Expression of P53 was only related to the histological grade $(p<0.05)$.

\section{Survival rate}

Univariate analysis showed that the OS and DFS of the patients were longer $(p<0.05)$ under the following conditions: low expression of P53 expression, adenocarcinoma pathology, high differentiation in histological grading, early stage $\mathrm{GC}$, absence of tumor thrombus, tumor size $<5$ $\mathrm{cm}$ and absence of lymph node metastasis (Figure 2 and Table 2).

COX multiple-factor analysis showed that histological grade, infiltration depth and P53 expression were independent factors that influenced DFS.
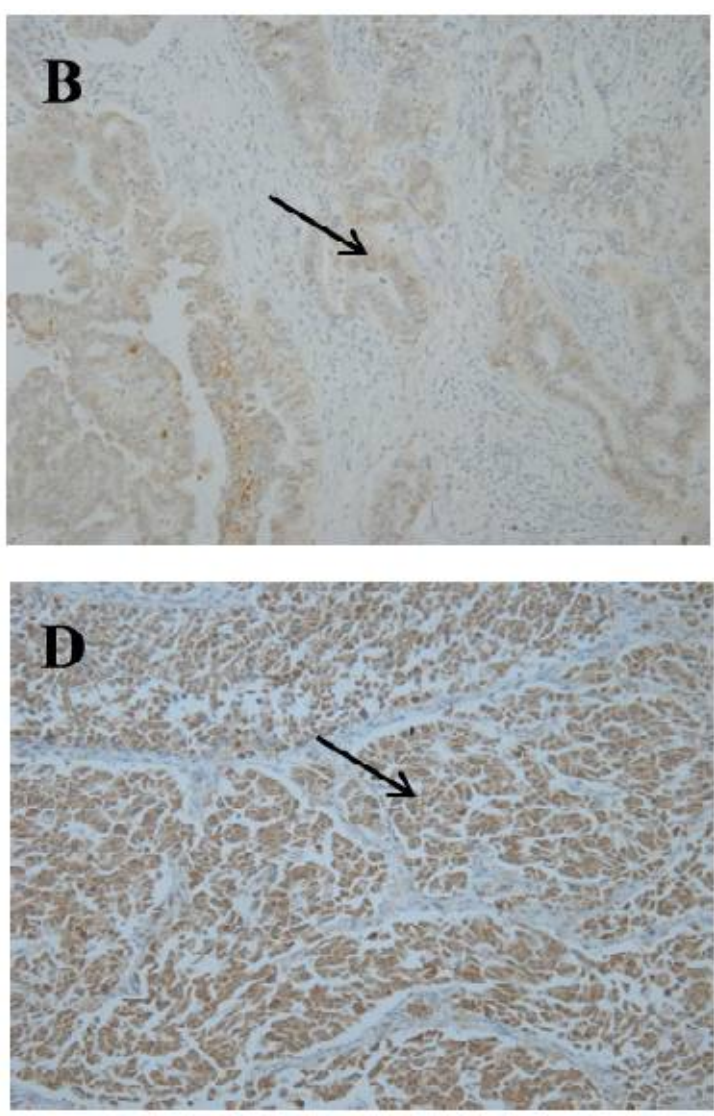

(B), P53 (C) and VEGF (D) ( $\times$ 200, Two-step GC IHC 
However, pathological type, presence of tumor thrombus, tumor size, lymph nodes metastasis, and chemotherapy group had no effect on DFS. The risk ratio of P53 on DFS was 0.406 , and 95 $\%$ confidence interval was $0.180-0.918$. Histological grade, infiltration depth, lymph node metastasis and P53 expression were independent factors that influenced OS. However, pathological type, presence of tumor thrombus, tumor size and chemotherapy group had no effect on OS. The risk ratio of P53 on OS was 0.548 , and $95 \%$ confidence interval was 0.325 - 0.924 (Table 3).

Table 1: Correlation between expression of EGFR, P53, HER-2, VEGF and clinico-pathological characteristics of GC

\begin{tabular}{|c|c|c|c|c|}
\hline \multirow{2}{*}{ Variable } & \multicolumn{4}{|c|}{ Positive rate (\%) } \\
\hline & EGFR & P53 & HER-2 & VEGF \\
\hline \multicolumn{5}{|l|}{ Gender } \\
\hline Male (124) & $23(88.5)$ & $51(86.4)$ & $24(96.0)$ & $59(83.1)$ \\
\hline Female (23) & $3(11.5)$ & $8(13.6)$ & $1(4.0)$ & $12(6.9)$ \\
\hline \multicolumn{5}{|l|}{ Age (years) } \\
\hline$\leq 60(101)$ & $17(65.4)$ & $41(69.5)$ & $15(60.0)$ & $47(66.2)$ \\
\hline$>60(46)$ & $9(34.6)^{\prime}$ & $18(30.5)$ & $10(40.0)$ & $24(33.8)$ \\
\hline \multicolumn{5}{|l|}{ Pathological stage } \\
\hline Adenocarcinoma (89) & $17(65.4)$ & $36(61.0)$ & $18(72.0)$ & $43(60.6)$ \\
\hline $\begin{array}{l}\text { Signet-ring cell } \\
\text { carcinoma (26) }\end{array}$ & $4(15.4)$ & $10(16.9)$ & $4(16.0)$ & $10(14.1)$ \\
\hline Mixed type (32) & 5 (19.2) & $13(22.0)$ & $3(12.0)$ & $18(25.4)$ \\
\hline \multicolumn{5}{|l|}{ Histological grade } \\
\hline Well to moderate (26) & 5 (19.2) & $6(10.2)^{a}$ & $5(20.0)$ & 13 (18.3) \\
\hline Poor (121) & $21(80.8)$ & $53(89.8)$ & $20(80.0)$ & $58(81.7)$ \\
\hline \multicolumn{5}{|l|}{ Stage } \\
\hline $\mathrm{I}(11)$ & $3(11.5)$ & $6(10.2)$ & $3(12.0)$ & $8(11.3)$ \\
\hline II (44) & $8(30.8)$ & $14(23.7)$ & 7 (28.0) & $17(23.9)$ \\
\hline III (86) & $15(57.7)$ & $37(62.7)$ & $15(60.0)$ & $42(59.2)$ \\
\hline IV (6) & $0(0)$ & $2(3.4)$ & $0(0)$ & $4(5.6)$ \\
\hline \multicolumn{5}{|l|}{ Size $(\mathrm{cm})$} \\
\hline $\mathrm{T} \leq 5(87.0)$ & $16(64.0)$ & $33(57.9)$ & $17(68.0)$ & $46(68.7)$ \\
\hline $\mathrm{T}>5(55.0)$ & $9(36.0)$ & $24(42.1)$ & $8(32)$ & $21(31.3)$ \\
\hline \multicolumn{5}{|l|}{ Cancer embolus } \\
\hline Negative (103) & 20 (76.9) & $41(69.5)$ & $17(68.0)$ & $46(67.6)$ \\
\hline Positive (41) & $6(23.1)$ & $18(30.5)$ & $8(32)$ & $22(32.4)$ \\
\hline
\end{tabular}

${ }^{a} P<0.05$, compared with "Poor" in histological grading

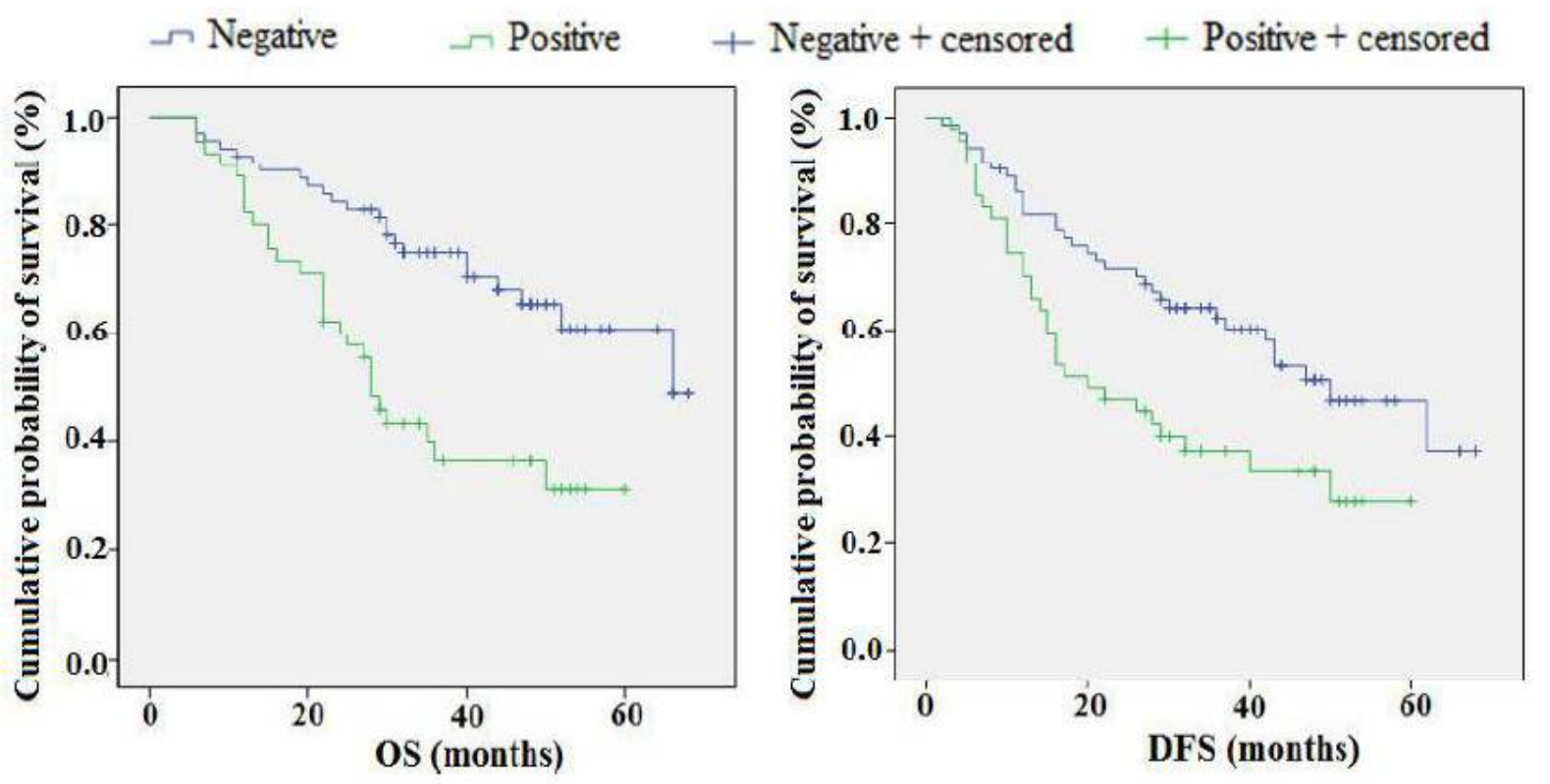

Figure 2: Univariate analysis of DFS and OS on expression of P53 
Table 2: Univariate analysis of different clinico-pathological factors

\begin{tabular}{|c|c|c|c|c|}
\hline Media & $\begin{array}{l}\text { disease-free survival } \\
\text { time (MDFS) }\end{array}$ & $P$-value & $\begin{array}{c}\text { Median overall survival } \\
\text { time (MOS) }\end{array}$ & $P$-value \\
\hline P53 & & 0.050 & & 0.008 \\
\hline Negative & $47 \pm 7.063$ & & 66 & \\
\hline Positive & $24 \pm 5.499$ & & $30 \pm 4.270$ & \\
\hline Pathologic stage & & 0.000 & & 0.000 \\
\hline Adenocarcinoma & $59 \pm 7.895$ & & Not available & \\
\hline $\begin{array}{l}\text { Signet-ring cell } \\
\text { carcinoma }\end{array}$ & $17 \pm 1.530$ & & $24 \pm 3.739$ & \\
\hline Mixed type & $40 \pm 4.778$ & & $50 \pm 9.964$ & \\
\hline Histological grade & & 0.033 & & 0.006 \\
\hline Well to moderate & Not available & & Not available & \\
\hline Poor & $30 \pm 6.057$ & & $47 \pm 9.858$ & \\
\hline Depth of invasion & & 0.000 & & 0.001 \\
\hline $\mathrm{T} 1-\mathrm{T} 2$ & Not available & & Not available & \\
\hline $\mathrm{T} 3-\mathrm{T} 4$ & $30 \pm 5.490$ & & $47 \pm 7.572$ & \\
\hline Lymphatic involvement & & 0.000 & & 0.005 \\
\hline Negative & Not available & & Not available & \\
\hline Positive & $29 \pm 4.717$ & & $44 \pm 8.832$ & \\
\hline Stage & & 0.000 & & 0.000 \\
\hline 1 & Not available & & Not available & \\
\hline II & Not available & & Not available & \\
\hline III & $22 \pm 4.319$ & & $30 \pm 6.306$ & \\
\hline IV & $21 \pm 6.859$ & & $24 \pm 4.899$ & \\
\hline Size $(\mathrm{cm})$ & & 0.001 & & 0.002 \\
\hline$T \leq 5$ & Not available & & Not available & \\
\hline $\mathrm{T}>5$ & $22 \pm 4.634$ & & $30 \pm 10.429$ & \\
\hline Cancer embolus & & 0.055 & & 0.047 \\
\hline Negative (103) & $50 \pm 8.478$ & & $66 \pm 9.923$ & \\
\hline Positive (41) & $24 \pm 6.701$ & & $31 \pm 7.468$ & \\
\hline
\end{tabular}

Table 3: Multivariate analysis of different clinico-pathological factors

\begin{tabular}{|c|c|c|c|c|c|c|}
\hline \multirow[t]{2}{*}{ Variable } & \multicolumn{2}{|c|}{ Recurrent risk } & \multirow{2}{*}{$\begin{array}{c}95 \% \\
\text { Confidence } \\
\text { interval }\end{array}$} & \multicolumn{2}{|c|}{ Survival risk } & \multirow{2}{*}{$\begin{array}{l}\text { 95\% Confidence } \\
\text { interval }\end{array}$} \\
\hline & $\begin{array}{c}P_{-} \\
\text {value }\end{array}$ & Odds ratio & & $\begin{array}{c}P_{-} \\
\text {value }\end{array}$ & $\begin{array}{l}\text { Odds } \\
\text { ratio }\end{array}$ & \\
\hline Histological grade & 0.026 & 1.782 & $1.275-2.492$ & 0.026 & 0.350 & $0.138-0.885$ \\
\hline Depth of invasion & 0.017 & 2.650 & $1.188-5.915$ & 0.008 & 0.067 & $0.009-0.488$ \\
\hline P53 & 0.030 & 0.406 & $0.180-0.918$ & 0.024 & 0.548 & $0.325-0.924$ \\
\hline Lymphatic involvement & & & & 0.019 & 0.453 & $0.234-0.877$ \\
\hline
\end{tabular}

\section{DISCUSSION}

P53 is a tumor suppressor gene located on $17 p 13.1$ chromosome. It is highly correlated with human tumors. The wild-type protein of P53 has a half-life of about $20-30 \mathrm{~min}$, and mutant P53 protein has been cetected by conventional immunohistochemical methods [9,10]. Lazăr et al analyzed 61 patients with GC, and the results showed that the expression of P53 was $41 \%$ [11]. In that study [11], the five-year survival rate for patients with P53 over-expression was $8 \%$, while for patients with low-expression of P53, the five-year survival rate was $22.2 \%(p=0.0326)$. In the present study, expression of P53 was 41 $\%$, and the expression was related to histological grade.

Studies by Geng et al [12] indicated that GC patients with P53 over-expression manifested significant resistance to 5-FU, Adriamycin and hydroxycamptothecine. In the present study, patients with low-expression of P53 did better than those who received priority adjuvant chemotherapy of 5-FU after surgery.

EGFR and HER-2, members of the family of epidermal growth factor receptors, are type I receptor tyrosine kinase. The binding of ligands to the receptors activates the intracellular signaling pathways, leading to proliferation of cell division differentiation $[13,14]$. EGFR is highly expressed in a variety of malignant tumors, where it promotes angiogenesis, tumor cell proliferation, adhesion, invasion and metastasis, while inhibiting tumor cell apoptosis [15]. HER-2 gene is located on 17q21 chromosome, and studies have shown that it is expressed $6-35 \%$ in GC [16]. Results obtained in the present study revealed that although there is gene homology in 
the two receptors, their expressions in GC were independent. However, further studies using a larger sample size are needed to verify the clinical relevance of these two genes in GC.

VEGF gene is located on 6p21.3 chromosome, and is composed of seven members: VEGF-A VEGF-B, VEGF-C, VEGF-D, VEGF-E, PIGF-1 and PIGF-2 [17]. VEGF is highly expressed in most of human malignant tumors; it promotes endothelial cell proliferation and increases vascular permeability [18]. In the present study, the expression of VEGF was $55.9 \%$, which indicated that the VEGF expression can be used as an indicator for evaluating prognosis GC.

\section{CONCLUSION}

The results obtained in the present study strongly suggest that the expressions of P53, EGFR, HER2 and VEGF could be used for evaluating the prognosis of GC and screening patients' benefits from adjuvant chemotherapy.

\section{DECLARATIONS}

\section{Acknowledgement}

None declared.

\section{Conflict of Interest}

No conflict of interest associated with this work.

\section{Contribution of Authors}

The authors declare that this work was done by the authors named in this article and all liabilities pertaining to claims relating to the content of this article will be borne by them.

\section{Open Access}

This is an Open Access article that uses a funding model which does not charge readers or their institutions for access and distributed under the terms of the Creative Commons Attribution License (http://creativecommons.org/licenses/by/ 4.0) and the Budapest Open Access Initiative (http://www.budapestopenaccessinitiative.org/rea d), which permit unrestricted use, distribution, and reproduction in any medium, provided the original work is properly credited.

\section{REFERENCES}

1. He PWS, Zhang X, Gao Y, Niu W, Dong N, Shi X, Geng $Y$, Ma $Q$, Li M,Jiang $B$ et al. Tspan5 is an independent favourable prognostic factor and suppresses tumour growth in gastric cancer. Oncotarget 2016; 7(26): 40160-40173.

2. Chen $W$, Zheng $R$, Baade $P D$, Zhang $S$, Zeng $H$, Bray $F$, Jemal A, Yu XQ, He J. Cancer statistics in China, 2015. CA Cancer J Clin 2016; 66((2): 115-132.

3. Yu J, Zhang Y, Leung LH, Liu L, Yang F, Yao X. Efficacy and safety of angiogenesis inhibitors in advanced gastric cancer: a systematic review and meta-analysis. Hematol Oncol 2016; 9(1): 111.

4. Cho HS, Mason K, Ramyar KX, Stanley AM, Gabelli SB, Denney DW Jr, Leahy DJ. Structure of the extracellular region of HER2 alone and in complex with the Herceptin Fab. Nature 2003; 421(6924): 756-760.

5. Vosmik M, Laco J, Sirak I, Beranek M, Hovorkova E, Vosmikova H, Drastikova M, Hodek M, Zoul Z, Odrazka $K$, et al. Prognostic significance of human papillomavirus (HPV) status and expression of selected markers (HER2/neu, EGFR, VEGF, CD34, p63, p53 and Ki67/MIB-1) on outcome after (chemo-) radiotherapy in patients with squamous cell carcinoma of uterine cervix. Pathol Oncol Res 2014; 20(1): 131-137.

6. GASTRIC (Global Advanced/Adjuvant Stomach Tumor Research International Collaboration) Group, Paoletti $X$, Oba K, Burzykowski T, Michiels S, Ohashi Y, Pignon JP, Rougier P, Sakamoto J, Sargent D, et al. Benefit of adjuvant chemotherapy for resectable gastric cancer: a meta-analysis. JAMA 2010; 303(17): 1729-1737.

7. Helsinki Do. The 59th World Medical Association. 2008.

8. Mullaney PJ, Wadley MS, Hyde C, Wyatt J, Lawrence G, Hallissey MT, Fielding JW. Appraisal of compliance with the UICC/AJCC staging system in the staging of gastric cancer. Union Internacional Contra la Cancrum/American Joint Committee on Cancer. $\mathrm{Br} \mathrm{J}$ Surg 2002; 89(11): 1405-1408.

9. Imai $S$, Kiyozuka $Y$, Nishimura $H$, Iwanaga $S$, Murakami $F$, Imamura K, Noda $T$, Haga S, Yakushiji $M$. Overexpression of the tumor-suppressor gene p53 in human ovarian tumor-tissues and its correlation with clinical stage. Int J Oncol 1994; 4(5): 1097-1103.

10. King JC, Lu QY, Li G, Moro A, Takahashi H, Chen M, Go VL, Reber HA, Eibl G, Hines OJ. Evidence for activation of mutated $p 53$ by apigenin in human pancreatic cancer. Biochim Biophys Acta 2012; 182(2): 593-604.

11. Lazăr D, Tăban S, Sporea I, Dema A, Cornianu M, Lazăr E, Goldiş A, Raţiu I, Vernic C. The immunohistochemical expression of the p53-protein in gastric carcinomas. Correlation with clinicopathological factors and survival of patients. Rom J Morphol Embryol 2010; 51(2): 249257.

12. Geng M, Wang L, Liu X, Cao Y. Relationship between Expression of P53,P16 and Chemosensitivity in Gastric Carcinoma. J Med Res 2010; 39(6): 79-81.

13. Xu H, Yu Y, Marciniak D, Rishi AK, Sarkar FH, Kucuk O, Majumdar AP. Epidermal growth factor receptor (EGFR)-related protein inhibits multiple members of the EGFR family in colon and breast cancer cells. Mol Cancer Ther 2005; 4(3): 435-442.

Trop J Pharm Res, June 2017; 16(6): 1250 
14. Christensen JG, Schreck RE, Chan E, Wang X, Yang C, Liu L, Cui J, Sun L, Wei J, Cherrington JM, et al. High levels of HER-2 expression alter the ability of epidermal growth factor receptor (EGFR) family tyrosine kinase inhibitors to inhibit EGFR phosphorylation in vivo. Clin Cancer Res 2001; 7(12): 4230-4238.

15. Lu X, Yang L, Lu C, Xu Z, Qiu H, Wu J, Wang J, Tong J, Zhu Y, Shen J. Molecular Role of EGFR-MAPK Pathway in Patchouli Alcohol-Induced Apoptosis and Cell Cycle Arrest on A549 Cells In Vitro and In Vivo. Biomed Res Int 2016; (2016): 4567580.

16. Matsui $Y$, Inomata $M$, Tojigamori $M$, Sonoda $K$, Shiraishi $N$, Kitano $S$. Suppression of tumor growth in human gastric cancer with HER2 overexpression by an antiHER2 antibody in a murine model. Int $\mathrm{J}$ Oncol 2005; 27(3): 681-685.

17. Koukourakis MI, Papazoglou D, Giatromanolaki A, Bougioukas G, Maltezos E, Sivridis E. VEGF gene sequence variation defines VEGF gene expression status and angiogenic activity in non-small cell lung cancer. Lung Cancer 2004; 46(3): 293-298.

18. Chen YH, Pan SL, Wang JC, Kuo SH, Cheng JC, Teng CM. Radiation-induced VEGF-C expression and endothelial cell proliferation in lung cancer. Strahlenther Onkol 2014; 190(12): 1154-1162. 